\title{
The home range of adult Phrynops geoffroanus (Testudines, Chelidae) in relation to sex and body mass
}

\author{
Márcia Marrie Pinheiro Müller ${ }^{1}$, Zaida Ortega ${ }^{1}$, Pâmela Castro Antunes ${ }^{1}$, Larissa Lopes Seino ${ }^{1}$, \\ Matheus Justino Hammarstron ${ }^{1}$, Ana Carolina França Balbino-Silva ${ }^{1}$, \\ Luiz Gustavo Rodrigues Oliveira-Santos ${ }^{1}$ \\ 1 Laboratory of Movement and Population Ecology, Institute of Biology, Universidade Federal de Mato Grosso do Sul, Cidade Universitária, \\ Av. Costa e Silva, Pioneiros, ZIP 79070-900, Campo Grande, Mato Grosso do Sul, Brazil \\ http://zoobank.org/E12B7A8F-F2FC-4C4F-923B-7A6B71A1D7A4 \\ Corresponding author: Márcia Marrie Pinheiro Müller (marciamarrie@hotmail.com)
}

Academic editor: G. Gollmann • Received 28 February 2019 • Accepted 8 November 2019 • Published 3 December 2019

\begin{abstract}
Studying how different variables influence the size and shape of animals' home ranges helps our understanding of the ecology of individuals and populations. This study aims to assess the effects of sex and body mass on home range size and the sexual differences in the use of terrestrial habitats of a population of aquatic turtles Phrynops geoffroanus from an urban area in Mato Grosso do Sul, Brazil. Turtles were captured along a river by active search, occasional encounter and hoop traps. Using individual VHF radio transmitters, 13 individuals ( 7 females and 6 males) were radio-tracked by homing in on the signal strength of the transmitter. Home ranges were estimated by $95 \%$ and $50 \%$ core one-dimensional fixed kernel and linear distance method. Home ranges were similar for both sexes $(\mathrm{t}=-0.50, \mathrm{DF}=12, p=0.62)$ and independent of body mass $(\mathrm{t}=-0.53, \mathrm{DF}=12, p=0.60)$. However, females seemed to use terrestrial habitats more than males (females = six recorded locations out of 767 points; males = none), probably to nest. To gain insight on how males and females use their space, it would be useful to focus future studies on the influence of sex in microhabitat selection of Phrynops geoffroanus. Finally, as sex did not influence home range, studying the contribution of other variables - both intrinsic, as age or personality, and extrinsic, as habitat composition or distribution of trophic resources - shaping the home ranges of the species is proposed.
\end{abstract}

\section{Key Words}

one-dimensional fixed kernel, radio-tracking, turtle, VHF transmitters

\section{Introduction}

Understanding how home ranges are arranged in the landscape helps us to identify the most important habitat traits influencing the ecology of a given species (Powell 2000). For example, we can study which habitat traits lead individuals to select or avoid a certain place (Sung et al. 2015; De la Quintana et al. 2017). Besides, assessing the degree of overlap between home ranges could reveal mating sys- tems and contribute to understanding population dynamics (Wone and Beauchamp 2003; Smith and Cherry 2016).

Many species of turtles have overlapping home ranges (e.g. Mesoclemmys dahli, Forero-Medina et al. 2011; Rafetus euphraticus, Ghaffari et al. 2014). The degree of overlap and home range size could be mediated by sex, with females generally using smaller areas and sharing 
them with multiple males (Harless et al. 2009; Bower et al. 2012). This is probably due to the different reproductive strategies of the two sexes, where males usually move extensively in search of females while females remain near nesting areas (Morreale et al. 1984; Souza 2004).

Body size could also influence the extension of the home range. Reptiles demonstrate positive relationships between body mass and home range size (Tamburello et al. 2015). Heavier lizards (Turner et al. 1969; Christian and Waldschmidt 1984) usually have larger home ranges, probably due to energetic requirements and sexual size dimorphism (Perry and Garland 2002). Body size in turtles positively influences home range in many species (Pérez-Santigosa et al. 2013; Slavenko et al. 2016). Furthermore, the length of linear home range is also influenced by body size (Roe and Georges 2008). Information about the home range of South American chelids is limited (Forero-Medina et al. 2011).

Phrynops geoffroanus (Schweigger, 1812) is a widely distributed species complex in Brazil (Rueda-Almonacid et al. 2007; van Dijk et al. 2014), including urban areas (Souza and Abe 2001). Individuals of this species are mainly carnivores and extremely aquatic. Besides, females can reach $35 \mathrm{~cm}$ of carapace length and body mass $2.5 \mathrm{~kg}$, being larger than males (Rueda-Almonacid et al. 2007). However, there is still a lack of knowledge about the home range of this common freshwater turtle in its many different habitats.

Our objective was to study the home range of $P$. geoffroanus. Specifically, we aimed to test if sex and body mass influenced home range and if there was a differential use of terrestrial habitat between sexes. Based on previous studies of other species, we hypothesized that heavier animals and males would have larger home ranges. Males would increase their movement areas to increase their chances of finding females, and females would move less, concentrating on smaller areas near nesting sites. For similar reasons, females would be more frequently found on land than males.

\section{Methods}

\section{Study area}

We conducted the study at a Private Natural Heritage Reserve (RPPN_"'Reserva Particular do Patrimônio Natural") of the Universidade Federal de Mato Grosso do Sul (UFMS; Campo Grande, Mato Grosso do Sul, Brazil; 20.4990S, 54.6134W; WGS84). The RPPN has an area of 50.11 ha (Imasul 2014), composed of a mosaic of savannah sensu stricto gallery forest and dense savannah forest (Bueno et al. 2013). The RPPN is enclosed by a continuous wire fence, separating it from the surrounding urban area (Fig. 1).

Within the RPPN, two streams (Cabaça and Bandeira) flow into the Amor Lake (Fig. 1). In the Cabaça Stream, industrial and residential waste is released into the wa- ter upstream from the study area. The stream is usually narrow ( $\sim 0.5-4 \mathrm{~m}$ wide) and shallow ( $<1 \mathrm{~m}$ deep) with stones and riverbanks along it, where $P$. geoffroanus can bask or access the forest. The current of the stream is normally slow, but increases both in speed, width and depth depending on the voracity of the rains, varying from 0.5 $12 \mathrm{~m}$ wide and $0.1-4.5 \mathrm{~m}$ deep dependent on rainfall. No aquatic vegetation is present in the stream, the stream bed and banks being composed of sand and clay soils, with a scattering of human garbage. The stream banks have exposed tree roots and holes, below the water level, that turtles can use as shelter. Upstream, there is a waterfall about $2.5 \mathrm{~m}$ high, that has a small reservoir of about $12 \mathrm{~m}$ at its widest point and $2 \mathrm{~m}$ deep at its deepest point. There are two basking sites on each side of the reservoir where $P$. geoffroanus are frequently observed. All individuals were captured at the Cabaça Stream, and locations were obtained at both the Cabaça and Bandeira Streams and the Amor Lake. We did not capture turtles in the Bandeira Stream because its entire access is limited due to dense vegetation that prevents spotting the individuals; it was difficult to find accessible parts of the stream that were not continuously too shallow, and freshwater turtles were rarely sighted compared to the Cabaça Stream.

\section{Sampling methods}

We captured $P$. geoffroanus individuals along a $200 \mathrm{~m}$ stretch of the Cabaça Stream (Fig. 1). Turtles were captured and recaptured from March 2015 to July 2016 by active search, occasional encounter and hoop traps (Fig. 1). Each (re)captured individual was weighed using digital scales (Marine Sports $25 \mathrm{~kg}$ ) to the nearest gram. In order to avoid a confounding effect of age, we only estimated the home range of adults. We considered adults those individuals showing a straight carapace length above 21 $\mathrm{cm}$ (Souza and Abe 2001) and weighing more than $1 \mathrm{~kg}$. Body mass was defined as the mean weight of each turtle, from all its (re)captures (ranging from just one capture to five recaptures). Individuals were sexed by comparing the tail length and cloaca position in relation to carapace (Rueda-Almonacid et al. 2007). Turtles were individually marked by notching the marginal scutes (Cagle 1939) and adding a corresponding number using epoxy paste (Durepoxi, Loctite) on the anterior or posterior margin of the carapace. As our study is part of a long-term project, digital photographs of the carapace and plastron were taken to help to identify individuals by their unique fingerprint colour pattern for future recognition. A total of 13 adult turtles ( 7 females and 6 males) were equipped with VHF (Very High Frequency) radio transmitters TXF-314G model (Telenax; Playa del Carmen, La Toscana, Mexico). Each transmitter was fixed to the carapace with epoxy paste (Durepoxi, Loctite). The equipment's weight was less than 7\% of each turtle's weight (Schubauer 1981). All individuals were released at their respective points of capture on the same day. 


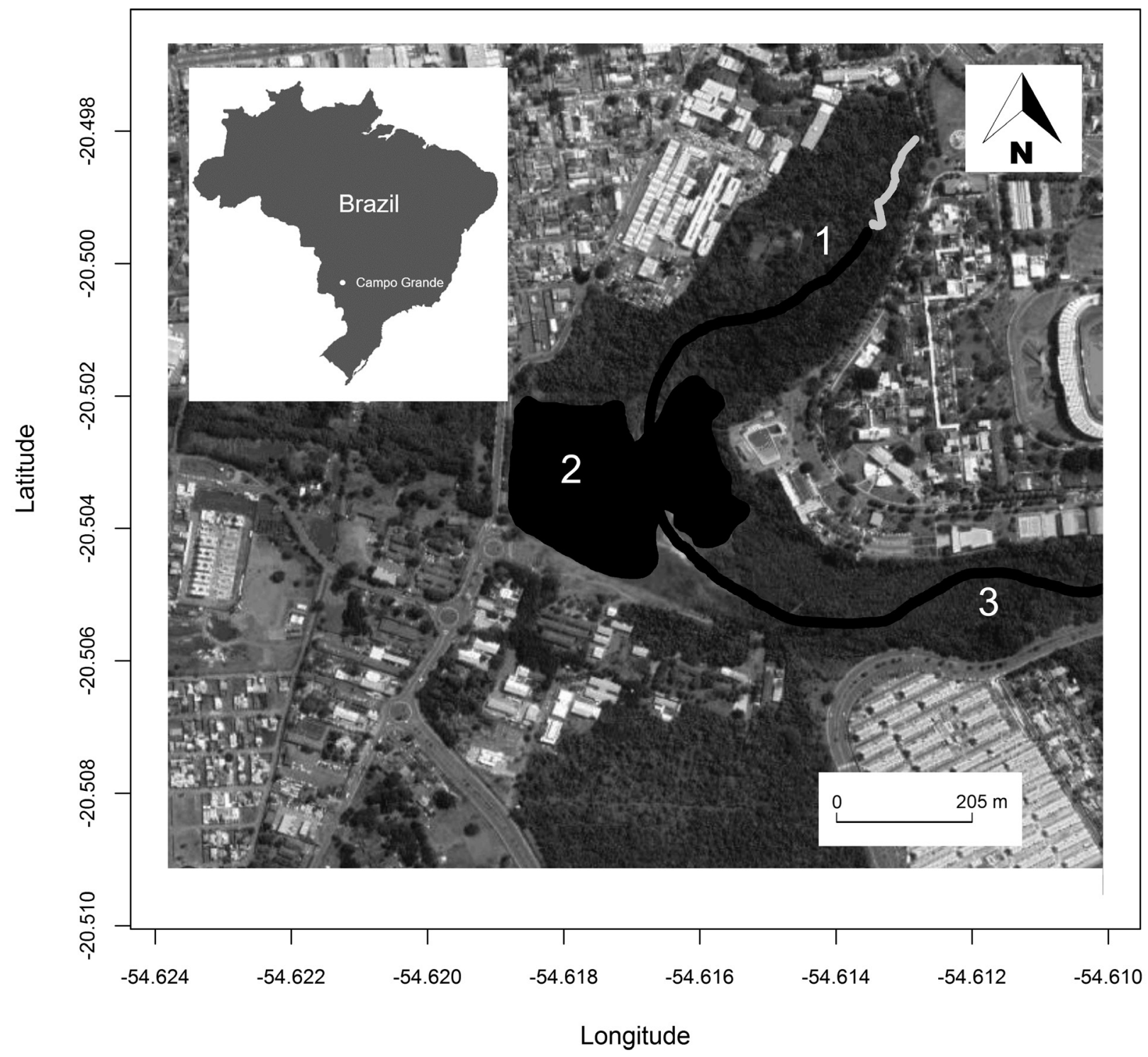

Figure 1. Study area at RPPN-UFMS (Campo Grande, MS, Brazil). 1. Cabaça Stream; 2. Amor Lake; 3. Bandeira Stream; Black area - the three water bodies used by Phrynops geoffroanus; White area - the $200 \mathrm{~m}$ stretch of Cabaça Stream where individuals were initially captured; Vertical axis - Latitude; Horizontal axis - Longitude.

\section{Radio-tracking}

Radio-tracking was conducted by a handheld receiver Icom (IC-R20) and antenna Telonics (Model RA-14). Turtle locations were obtained between April 2015 and October 2016, from two to seven days per week, with a maximum of one location per day and individual, in order to guarantee data independence. We took all locations during the day, between 7:00 $\mathrm{h}$ and 18:00 $\mathrm{h}$, according to the activity period of this species (Rueda-Almonacid et al. 2007). One VHF radio-tracked female (ID F2, Table 1) was also monitored by a Modified-GPS (model i-gotUGPS logger 120; Mobile Action Technology; New Taipei, Taiwan), for testing purposes. Its GPS monitoring occurred simultaneously to the VHF monitoring, but the first lasted a shorter time than the second. We included all data of the female F2 (GPS and VHF) for analysis together with the data from the other individuals. During the study, we started monitoring each individual at a different date, when we captured it. Thus, the number of locations varied according to the amount of time the VHF of each individual was functioning (Tables 1, 2). The individual's locations were obtained by homing in on the signal strength of the transmitter. Locations were determined: (1) by directly observing the individual, (2) when the handheld receiver detected the VHF signal at the minimal possible distance $(\sim 1 \mathrm{~m})$, or (3) by triangulation, when there were interferences. Minimal possible distance occurred when we were likely very near to the radio-tracked individual, but it was not possible to see it, for example because of turbid water or because it was inside a refuge. In these cases, we recorded the point where the strongest radio-signal was detected. Interferences were not strong enough to incapacitate estimating the location of the radio-tracked individual. The signal in the 
shallow Cabaça Stream was not static interfered and the water depth did not affect the signal reception. Locations were recorded using a handheld GPS unit (model Oregon 450; Garmin; Miami, Florida, USA; accuracy of 5-12 m).

\section{Data analyses}

The home ranges of $P$. geoffroanus were estimated using a $95 \%$ fixed kernel, with $50 \%$ as the core area (Worton 1989) and applying $h$ of reference (see Silverman 1986) as a smoothing parameter. Specifically, a one-dimensional fixed kernel was applied, which only considers the density of points distributed along the stream. Home ranges were estimated using $k d e()$ function available at $k s$ package (Chacón and Duong 2018). We also estimated the minimum linear home range (Ldist), by connecting the two most extreme points among the individual's locations (Kornilev et al. 2010). Because locations of VHF transmitters were obtained in UTM coordinates (two-dimensional locations), we needed to rescale them to transform them in one-dimensional locations. We did this by simply obtaining the linear distance from an arbitrary starting point located at the source of the river. The $\mathrm{R}$ code to rescale relocations, estimations of one-dimensional kernel, cut isopleths of probability and plots of home range on maps are available as Suppl. material 1. We tested the effects of sex, body mass and the interaction of sex-body mass on the home range (for the 95\% fixed kernel) using an Analyses of Covariance (ANCOVA). Maps for the figures were downloaded from GoogleAPP using the RgoogleMaps package of R (Loecher 2012), where forest polygons were drawn by eye over Google Earth images. All analyses were run in $\mathrm{R}$ software version 3.5.0 (R Core Team 2018).

\section{Results}

Body mass varied between $2.03-3.61 \mathrm{~kg}$ for females (Table 1) and 1.45-1.98 kg for males (Table 2). We recorded a total of 767 locations from the 13 radio-tracked adult individuals (mean overall individuals' locations $=59$, mean overall Ldist $=560 \mathrm{~m}$, Table 2 ). The main concentration of individuals' points was established in the stretch of the Cabaça Stream, extending to the Amor Lake and the Bandeira Stream for some individuals (Fig. 2). The female F2's GPS functioned for two months, providing overall 67 locations from 23 days from one to eight locations/day (Table 1). The mean home range of females was $330 \mathrm{~m}$ (1D Kernel 95\%), $80 \mathrm{~m}$ for the core area (1D Kernel 50\%) and $595 \mathrm{~m}$ for the minimum linear home range (Table 1). For males, the mean home range was 180 m (1D Kernel 95\%), $44 \mathrm{~m}$ for core area (1D Kernel 50\%), and $519 \mathrm{~m}$ for the minimum linear home range (Table 2). The home range was not influenced by sex $(\mathrm{t}=-0.50$, DF $=12, p=0.62)$ or body mass $(\mathrm{t}=-0.53, \mathrm{DF}=12, p=$ $0.60)$. Finally, the interaction between sex and body mass was also not significant $(\mathrm{t}=0.23, \mathrm{DF}=12, p=0.81)$. We recorded three females (a total of 6 recorded locations) and no males in terrestrial habitats (Tables 1,2).

Table 1. Distance travelled by radio-tracked Phrynops geoffroanus females at the studied area (Campo Grande, MS, Brazil). ID individual; Bm - body mass; LT - locations recorded in terrestrial habitat; $\mathbf{N}$ - number of recorded locations; Time - number of days elapsed from first to last recorded location; Ldist - minimum linear home range; K1d95 - 1D Kerne1 95\%; K1d50 - 1D Kernel $50 \% ; \mathbf{k g}$ - kilograms; $\mathbf{m}$ - meters.

\begin{tabular}{|c|c|c|c|c|c|c|c|c|}
\hline ID & Bm (kg) & LT & Period of monitoring & N (locations) & Time (days) & Ldist (m) & K1d95 (m) & K1d50 (m) \\
\hline$\overline{\text { F1 }}$ & 2.30 & - & September/16-October/16 & 15 & 43 & 192 & 212 & 64 \\
\hline F2 & 2.03 & 1 & May/15-August/15 & 135 & 96 & 508 & 281 & 78 \\
\hline F3 & 3.19 & 3 & April/15-October/16 & 180 & 574 & 255 & 270 & 78 \\
\hline F4 & 3.06 & 2 & April/15-July/15 & 59 & 98 & 1019 & 638 & 146 \\
\hline F5 & 2.28 & - & June/15-August/15 & 62 & 87 & 1360 & 666 & 144 \\
\hline F6 & 3.61 & - & June/15-August/15 & 29 & 51 & 14 & 79 & 24 \\
\hline F7 & 2.83 & - & July/16-October/16 & 24 & 95 & 818 & 164 & 29 \\
\hline Mean for females & 2.75 & - & - & 72 & 149 & 595 & 330 & 80 \\
\hline
\end{tabular}

Table 2. Distance travelled by radio-tracked Phrynops geoffroanus males at the studied area (Campo Grande, MS, Brazil). ID individual; Bm - body mass; LT - locations recorded in terrestrial habitat; $\mathbf{N}$ - number of recorded locations; Time - number of days elapsed from first to last recorded location; Ldist - minimum linear home range; K1d95 - 1D Kernel 95\%; K1d50 - 1D Kernel 50\%; kg - kilograms; m - meters; Mean overall - average for females and males.

\begin{tabular}{|c|c|c|c|c|c|c|c|c|}
\hline ID & Bm (kg) & LT & Period of monitoring & N (locations) & Time (days) & Ldist (m) & K1d95 (m) & K1d50 (m) \\
\hline M1 & 1.53 & - & April/15-August/15 & 94 & 143 & 104 & 114 & 29 \\
\hline M2 & 1.79 & - & July/15-December/15 & 80 & 161 & 14 & 79 & 29 \\
\hline M3 & 1.98 & - & September/16-October/16 & 14 & 43 & 763 & 144 & 29 \\
\hline M4 & 1.45 & - & June/15-June/15 & 18 & 18 & 803 & 213 & 54 \\
\hline M5 & 1.91 & - & July/15-August/15 & 22 & 30 & 123 & 109 & 29 \\
\hline M6 & 1.87 & - & April/16-September/16 & 35 & 159 & 1311 & 421 & 94 \\
\hline Mean for males & 1.75 & - & - & 43 & 92 & 519 & 180 & 44 \\
\hline Mean overall & 2.29 & - & - & 59 & 122 & 560 & 260 & 63 \\
\hline
\end{tabular}




\section{Discussion}

Home ranges were similar between males and females of $P$. geoffroanus living in an urban area of the Brazilian central-west region. Similar results were found for Clemmys insculpta in Canada (Arvisais et al. 2002), Kinosternon integrum in México (Pérez-Pérez et al. 2017) and Pseudemys concinna suwanniensis in the United States (Kornilev et al. 2010). A meta-analysis on the home range of 64 species of turtles found that body mass explains little variation in home range size (Slavenko et al. 2016). Therefore, our results about the influence of body mass on home range size reinforce these previous findings.

As expected, the studied turtles used aquatic habitats almost exclusively, with only six points (of 767) detected
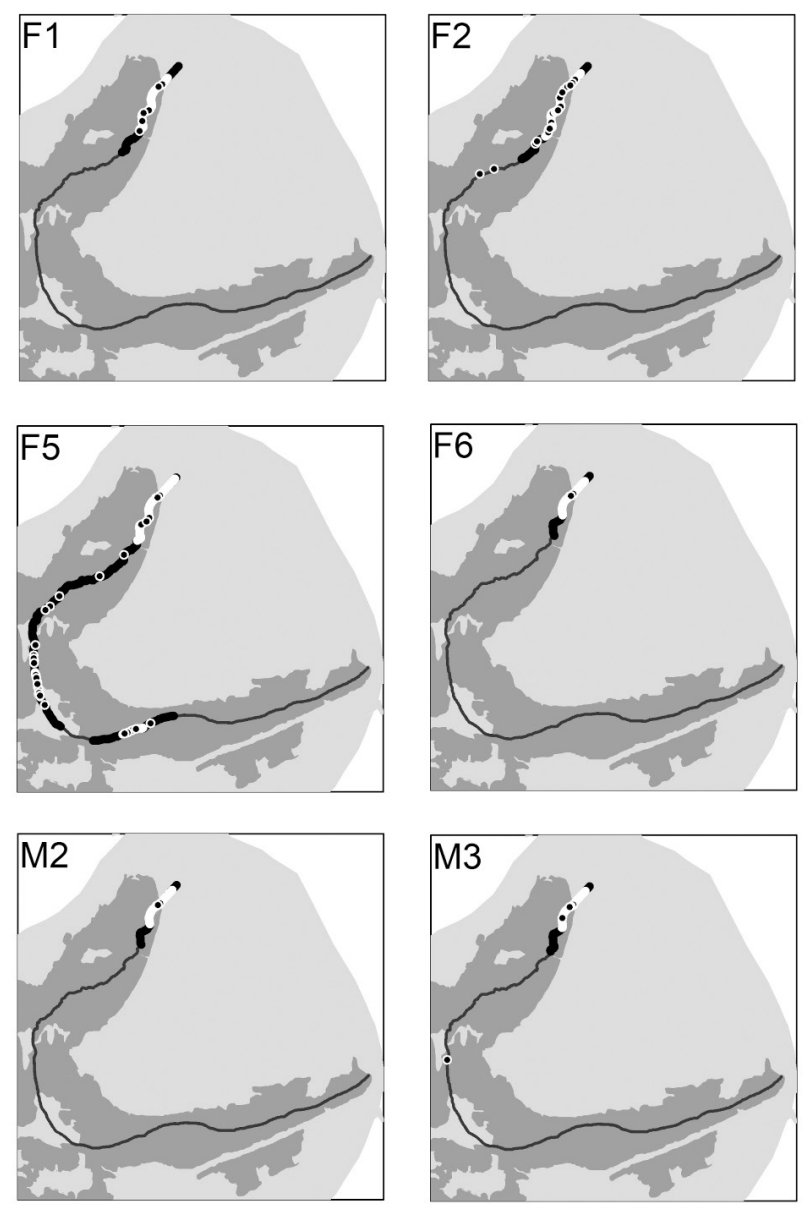
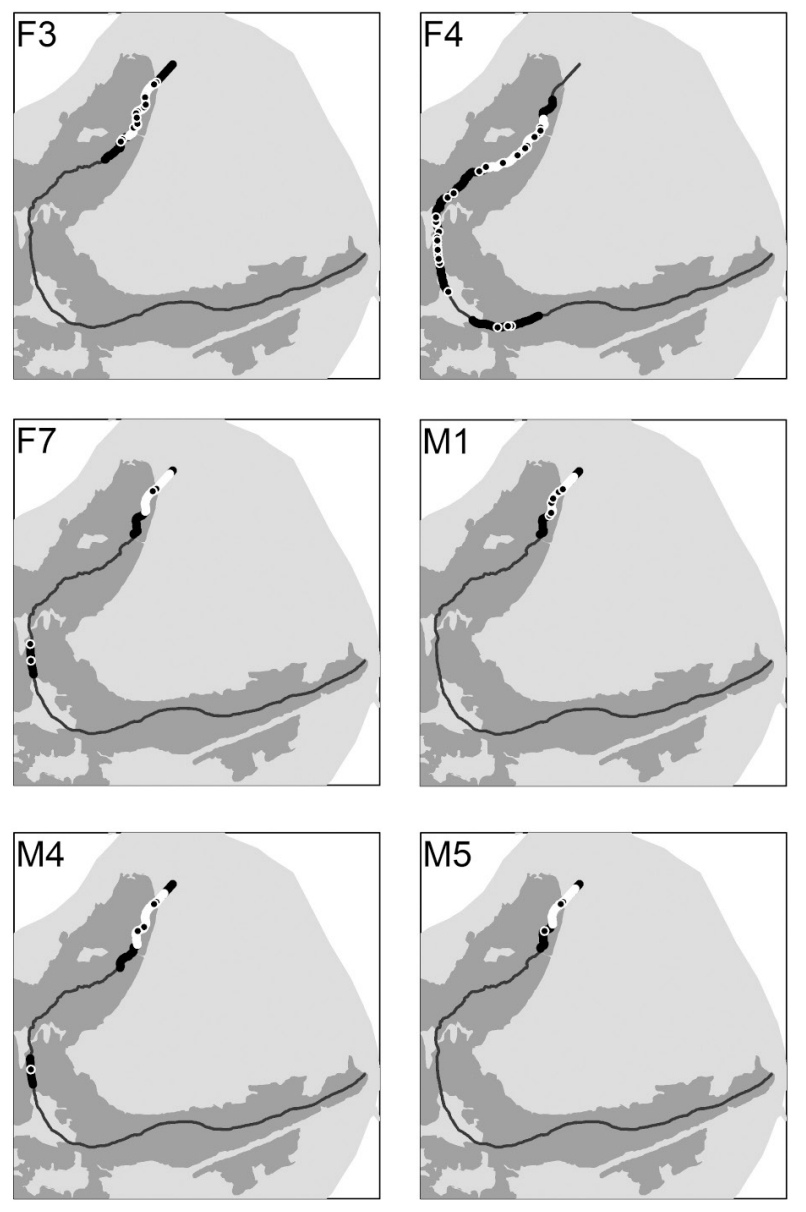

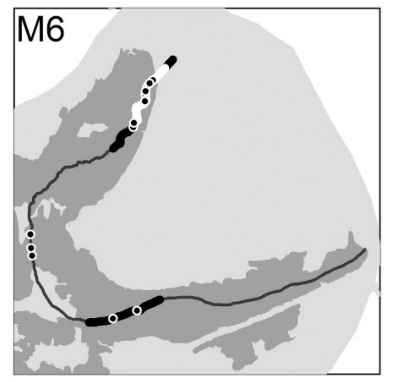

in terrestrial habitats. Kernel estimators barely represent the importance of a habitat that is used in a disproportionately small frequency (Powell 2000). One female (individual F3, see Fig. 2) showed some isolated points in terrestrial habitat surrounding the Cabaça stretch, which suggests nesting activity. The same female was found nesting near the Cabaça stretch at another time as well. Another female (individual F4, see Fig. 2) was also found in a terrestrial habitat, although nesting was not observed.

Handling the turtles would potentially impact their movement ecology estimations because of a propensity to escape after being released. Souza et al. (2008) demonstrated that $P$. geoffroanus initially increased their moved distance after release, and then it was gradually reduced again after 48 hours. The individuals of our study have been monitored

Figure 2. Home range of seven females (F1-F7) and six males (M1-M6) of Phrynops geoffroanus. White area - 1D Kernel 50\%; Black area - 1D Kernel 95\%; Dark grey - water bodies; Medium grey - forested area; Light grey - not forested area; Black circles - individual observations of $P$. geoffroanus. 
for 18-574 days, which substantially exceeds this period of $48 \mathrm{~h}$ on which they could have moved longer distances as a response to manipulation. In addition, our experience - as a part of the long-term research project where we conduct continuous observations at the study area - is that most individuals continued to be directly observed at the study site after capture. Besides, while VHF was operating, no radio-tracked individual left the study area.

In urban areas, P. geoffroanus are known to forage within the water, and their diet is mainly composed of larvae of Chironomus sp. (Martins et al. 2010). Since incursions in terrestrial habitats are rare, it is difficult to gather a high number of terrestrial locations in a study about home range as the present one. However, the fact that females need terrestrial habitats to nest is vital for the long-term management of these populations. In urban areas, many turtles could suffer car collisions when trying to get across the streets searching for nesting places and females could not find suitable places to nest near streams. Therefore, greater effort should be devoted to assessing the locations of terrestrial habitat used by this species throughout the year and their characteristics regarding habitat structure. This is required to inform urban planners and conservationists on how to design and manage urban natural reserves taking the viability of freshwater turtle populations into account.

\section{Conclusions}

Our study showed no differences in home range between sexes. Terrestrial habitats were only used by females for nesting. Further studies should expand our understanding on which factors modulate $P$. geoffroanus home range size and shape in urban and natural populations. In addition, it is important to get more insight into the characteristics of aquatic habitats that are used, selected and/or avoided by males and females of $P$. geoffroanus throughout their daily and annual activity. Finally, assessing which terrestrial areas are used for nesting throughout the year is also essential to inform urban planners on the management of urban natural reserves and ensure the preservation of freshwater turtles in cities.

\section{Acknowledgements}

We thank FUNDECT (Fundação de Apoio ao Desenvolvimento do Ensino, Ciência e Tecnologia do Estado de Mato Grosso do Sul) and CAPES (Coordenação de Aperfeiçoamento de Pessoal de Nível Superior) for investing in our research and to the Postgraduate Program in Animal Biology of the UFMS for supporting our study. A postdoctoral fellowship PNPD/CAPES (\#1694744) supported Z.O. All capture and marking methods were approved by the Bioethics Committee of the UFMS (CEUA-UFMS; permit number 41181-1) and the National Environmental Agency (MMA-SISBIO; permit number 49802-1).

\section{References}

Arvisais M, Bourgeois JC, Lévesque E, Daigle C, Masse D, Jutras J (2002) Home range and movements of a Wood Turtle (Clemmys insculpta) population at the northern limit of its range. Canadian Journal of Zoology 80(3): 402-408. https://doi.org/10.1139/z02-013

Bower DS, Hutchinson M, Georges A (2012) Movement and habitat use of Australia's largest snake-necked turtle: implications for water management. Journal of Zoology 287(1): 76-80. https://doi. org/10.1111/j.1469-7998.2011.00891.x

Bueno ML, Neves DRM, Souza AF, Junior EO, Junior GAD, Pontara V, Laura VA, Ratter JA (2013) Influence of edaphic factors on the floristic composition of an area of cerradão in the Brazilian central-west. Acta Botanica Brasilica 27(2): 445-455. https://doi. org/10.1590/S0102-33062013000200017

Cagle FR (1939) A system of marking turtles for future identification. Copeia 1939(3): 170-173. https://doi.org/10.2307/1436818

Chacón JE, Duong T (2018) Multivariate kernel smoothing and its applications. Chapman \& Hall/CRC, New York, 226 pp. https://doi. org/10.1201/9780429485572

Christian KA, Waldschmidt S (1984) The relationship between lizard home range and body size: a reanalysis of the data. Herpetologica 40(1): 68-75.

De la Quintana P, Rivas JA, Valdivia F, Pacheco LF (2017) Home range and habitat use of Beni anacondas (Eunectes beniensis) in Bolivia. Amphibia-Reptilia 38(4): 547-553. https://doi. org/10.1163/15685381-00003124

Forero-Medina G, Cárdenas-Arevalo G, Castaño-Mora OV (2011) Abundance, home range, and movement patterns of the endemic species Dahl's Toad-headed Turtle (Mesoclemmys dahli) in Cesar, Colombia. Chelonian Conservation and Biology 10(2): 228-236. https://doi.org/10.2744/CCB-0929.1

Ghaffari H, Ihlow F, Plummer MV, Karami M, Khorasani N, Safaei-Mahroo B, Rödder D (2014) Home range and habitat selection of the endangered Euphrates Softshell Turtle Rafetus euphraticus in a fragmented habitat in southwestern Iran. Chelonian Conservation and Biology 13(2): 202-215. https://doi.org/10.2744/CCB-1071.1

Harless ML, Walde AD, Delaney DK, Pater LL, Hayes WK (2009) Home range, spatial overlap, and burrow use of the Desert Tortoise in the West Mojave Desert. Copeia 2009(2): 378-389. https://doi. org/10.1643/CE-07-226

Imasul (2014) Reserva Particular do Patrimônio Natural-RPPN http://www. imasul.ms.gov.br/setores/gerencias/unidades-de-conservacao/reserva-particular-do-patrimonio-natural-rppn/ [Accessed on 16.06.2019]

Kornilev YV, Dodd Jr. CK, Johnston GR (2010) Linear home range, movement, and spatial distribution of the Suwannee Cooter (Pseudemys concinna suwanniensis) in a Blackwater River. Chelonian Conservation and Biology 9(2): 196-204. https://doi.org/10.2744/CCB-0790.1

Loecher M (2012) Package 'RgoogleMaps'. R package version 1.2.0.2. http://cran.r-project.org/

Martins FI, Souza FL, Costa HTM (2010) Feeding habits of Phrynops geoffroanus (Chelidae) in an urban river in central Brazil. Chelonian Conservation and Biology 9(2): 294-297. https://doi.org/10.2744/ CCB-0809.1

Morreale SJ, Gibbons JW, Congdon JD (1984) Significance of activity and movement in the Yellow-bellied Slider Turtle (Pseudemys scripta). Canadian Journal of Zoology 62(6): 1038-1042. https:// doi.org/10.1139/z84-148 
Pérez-Pérez A, López-Moreno AE, Suárez-Rodríguez O, Rheubert JL, Hernández-Gallegos O (2017) How far do adult turtles move? Home range and dispersal of Kinosternon integrum. Ecology and Evolution 7(20): 8220-8231. https://doi.org/10.1002/ece3.3339

Pérez-Santigosa N, Hidalgo-Vila J, Díaz-Paniagua C (2013) Comparing activity patterns and aquatic home range areas among exotic and native turtles in southern Spain. Chelonian Conservation and Biology 12(2): 313-319. https://doi.org/10.2744/CCB-1028.1

Perry G, Garland Jr. T (2002) Lizard home ranges revisited: effects of sex, body size, diet, habitat, and phylogeny. Ecology 83(7): 1870 1885. https://doi.org/10.2307/3071771

Powell RA (2000) Animal home ranges and territories and home range estimators. In: Boitani L, Fuller TK (Eds) Research techniques in animal ecology: controversies and consequences. Columbia University Press, New York, 65-110. https:/www.researchgate.net/profile/ Roger_Powell2/publication/236982035_Animal_Home_Ranges_and_Territories_and_Home_Range_Estimators/links/54188bc50cf2218008bf4012/Animal-Home-Ranges-and-Territories-and-Home-Range-Estimators.pdf

R Core Team (2018) R: A language and environment for statistical computing. Foundation for Statistical Computing, Vienna.

Roe JH, Georges A (2008) Terrestrial activity, movements and spatial ecology of an Australian freshwater turtle, Chelodina longicollis, in a temporally dynamic wetland system. Austral Ecology 33(8): 1045-1056. https://doi.org/10.1111/j.1442-9993.2008.01877.x

Rueda-Almonacid JV, Carr JL, Mittermeier RA, Rodríguez-Mahecha JV, Mast RB, Vogt RC, Rhodin AGJ, de la Ossa-Velásquez J, Rueda JN, Mittermeier CG (2007) Las tortugas y los cocodrilianos de los países andinos del trópico. Vol. 6. Conservación Internacional, Bogotá, 538 pp. http://www.iucn-tftsg.org/wp-content/uploads/file/ Articles/Rueda-Almonacid_etal_2007.pdf

Schubauer JP (1981) A reliable radio-telemetry tracking system suitable for studies of chelonians. Journal of Herpetology 15(1): 117-120. https://doi.org/10.2307/1563656

Schweigger AF (1812) Prodromus monographiae Cheloniorum. Archiv für Naturwissenschaft und Mathematik, Königsberger, 462 pp.

Silverman BW (1986) Density estimation for statistics and data analysis. Chapman and Hall/CRC, New York, 176 pp. https://doi. org/10.1007/978-1-4899-3324-9

Slavenko A, Itescu Y, Ihlow F, Meiri S (2016) Home is where the shell is: predicting turtle home range sizes. Journal of Animal Ecology 85(1): 106-114. https://doi.org/10.1111/1365-2656.12446

Smith LM, Cherry RP (2016) Movement, seasonal activity, and home range of an isolated population of Glyptemys muhlenbergii, Bog Turtle, in the southern Appalachians. Southeastern Naturalist 15(2): 207-219. https://doi.org/10.1656/058.015.0202

Souza FL (2004) Uma revisão sobre padrões de atividade, reprodução e alimentação de cágados brasileiros (Testudines, Chelidae). Phyllomedusa 3(1): 15-27. https://doi.org/10.11606/issn.2316-9079. v3ilp15-27
Souza FL, Abe AS (2001) Population structure and reproductive aspects of the freshwater turtle, Phrynops geoffroanus, inhabiting an urban river in southeastern Brazil. Studies on Neotropical Fauna and Environment 36(1): 57-62. https://doi.org/10.1076/snfe.36.1.57.8887

Souza FL, Raizer J, Costa HTM, Martins FI (2008) Dispersal of Phrynops geoffroanus (Chelidae) in an urban river in central Brazil. Chelonian Conservation and Biology 7(2): 257-261. https://doi. org/10.2744/CCB-0698.1

Sung Yik-Hei, Hau BCH, Karraker NE (2015) Spatial ecology of endangered Big-headed Turtles (Platysternon megacephalum): Implications of its vulnerability to illegal trapping. The Journal of Wildlife Management 79(4): 537-543. https://doi.org/10.1002/jwmg.861

Tamburello N, Côté IM, Dulvy NK (2015) Energy and the scaling of animal space use. The American Naturalist 186(2): 196-211. https:// doi.org/10.1086/682070

Turner FB, Jennrich RI, Weintraub JD (1969) Home ranges and body size of lizards. Ecology 50(6): 1076-1081. https://doi.org/10.2307/1936898

van Dijk PP, Iverson JB, Rhodin AGJ, Shaffer HB, Bour R (2014) Turtles of the world, $7^{\text {th }}$ edition: annotated checklist of taxonomy, synonymy, distribution with maps, and conservation status. Chelonian Research Monographs (5): 329-479. https://doi.org/10.3854/ crm.5.000.checklist.v7.2014

Wone B, Beauchamp B (2003) Movement, home range, and activity patterns of the Horned Lizard, Phrynosoma mcallii. Journal of Herpetology 37(4): 679-686. https://doi.org/10.1670/267-01A

Worton BJ (1989) Kernel methods for estimating the utilization distribution in home-range studies. Ecology 70(1): 164-168. https://doi. org/10.2307/1938423

\section{Supplementary material 1}

\section{Code used to estimate the home range of Phrynops geoffroanus}

Authors: Márcia Marrie Pinheiro Müller, Zaida Ortega, Pâmela Castro Antunes, Larissa Lopes Seino, Matheus Justino Hammarstron, Ana Carolina França Balbino-Silva, Luiz Gustavo Rodrigues Oliveira-Santos

Data type: ZIP file

Explanation note: Code to rescale relocations, estimations of one-dimensional kernel, cut isopleths of probability and plots of home range on maps.

Copyright notice: This dataset is made available under the Open Database License (http://opendatacommons.org/licenses/ odb1/1.0/). The Open Database License (ODbL) is a license agreement intended to allow users to freely share, modify, and use this Dataset while maintaining this same freedom for others, provided that the original source and author(s) are credited. Link: https://doi.org/10.3897/herpetozoa.32.e38237.supp11 